\title{
Arend, Silvia Maria F.; Moura, Esmeralda Blanco B. de; Sosenski, Susana (org.) Infâncias e juventudes no século XX: histórias latino-americanas
}

\author{
José Pacheco dos Santos Júnior*
}

Ponta Grossa: Todapalavra, 2018. 368 p.

“Atenção! atenção! É uma nova era no Brasil, menino veste azul e menina veste rosa" (Pains, 2019). O ano de 2019 acabara de desabrochar quando a recém-empossada ministra da Mulher, Família e Direitos Humanos, Damares Alves, proferiu tais palavras sob coro e aplausos calorosos. Carregada de significados e intenções, a declaração de Damares também dá voz, involuntariamente, ao questionamento: quais os atributos da infância na História do Tempo Presente? Se existem, quem os criou e com quais interesses?

Em livro publicado em 2018 pela editora Todapalavra e articulado em cinco partes - família, consumo, ditaduras, menoridade e trabalho - com prólogo assinado pela historiadora Elena Jackson Albarrán, estudiosos latino-americanos transitaram por distintos âmbitos e métodos da historiografia contemporânea, movidos pela investigação sobre as trajetórias e particularidades das Infâncias e juventudes no século XX.

De início, a sinuosa relação entre o Direito Penal e a questão do castigo é levantada por Esmeralda Moura. Também mirando a dimensão da lei, José Carlos Cardozo utiliza-se de processos judiciais que abordam a tutela de crianças na Primeira República. Valendo-se do mesmo recorte de tempo, Ismael Alves aborda a preocupação brasileira com a maternidade e assistência à infância. Já Silvia Maria Arend fecha o bloco da seção "família" elucidando as trajetórias de três meninas que vivenciaram a "Era dos Extremos", o século XX no dizer de Eric Hobsbawm, em consonância com o mundo do trabalho. Em visão panorâmica, esses quatro capítulos iniciais do livro trazem Michel Foucault à discussão sobre a História da Infância e Juventude no Brasil, revolvendo

\footnotetext{
* Universidade de São Paulo (USP), São Paulo, SP, Brasil. josepsjunior@usp.br <https://orcid.org/00000001-5081-7519>
} 
a lógica de discursos individuais e coletivos, o arsenal de intenções de sujeitos - educadores, juristas, médicos e as próprias crianças e jovens, como na contribuição de Arend - e os mecanismos de articulações e práticas.

O segundo bloco de textos, "consumo", é um exemplo da diversidade de perspectivas disponíveis aos historiadores contemporâneos. Seja o pensamento e a produção intelectual de Clarice Lispector direcionado ao público infantil nas décadas de 1960 e 1970, em reflexão de Alejandra Josiowicz; as celebrações e origens do Dia da Criança no México, no capítulo assinado por Susana Sosenski, e o lugar da motocicleta nos desejos de consumo de jovens brasileiros nos confins do século XX, em texto de Cristiano José Pereira. De modo geral, sobressaem, nas três narrativas dessa seção, os distintos modelos de infância e juventude que foram sendo gradativamente sedimentados em canais múltiplos, como a literatura, a imprensa e a indústria da propaganda.

Falar de século XX na América Latina também implica tocar nas ditaduras ocorridas na região, tema da terceira parte. Patricia Castillo, em suas análises, problematiza os elementos teórico-metodológicos que possibilitam esmiuçar o mosaico de experiências infantis e de cultura material no Chile dos tempos ditatoriais. Na sequência, Isabella Cosse elege a Argentina da década de 1970 como campo de reflexão, formulando a hipótese de que a "infância - como sujeitos e como noção - teve uma significação política central” (p. 234, tradução livre) na conjuntura que se estabeleceu entre "revolução" e "contrarrevolução" no Cone Sul.

A penúltima seção da coletânea, "menoridade", apresenta os capítulos dos historiadores Ailton José Morelli e Humberto Miranda. Caro aos estudiosos das humanidades, o termo que dá título à seção é gerador de profundas querelas e discussões acadêmicas. Ser "menor" no Brasil republicano, como defendem as pesquisas consolidadas da área (Passetti, 1991; Faleiros, 2009; Londoño, 1991), era pertencer a uma categoria marginalizada econômica e socialmente, como também alvo privilegiado das atenções do poder público. Ciente disso, Morelli analisa os debates fomentados no decorrer das Semanas de Estudos do Problema de Menores, ocorridas entre 1948 e 1951, ao passo que Miranda examina a ideia de família ideal nas ações assistenciais e nos discursos propalados pela Fundação Nacional do Bem-Estar do Menor (Funabem) nos anos de ditadura militar no Brasil.

Fechando a obra, a parte intitulada "trabalho" traz duas contribuições salutares no entendimento acerca do labor infantojuvenil. Enquanto Eduardo Netto Nunes direciona o seu olhar à primeira metade do século XX, com ênfase às discussões e aprovações dos Congressos Pan-americanos da Criança, Antero 
Maximiliano Reis explora a década de 1990, as dimensões do trabalho dos vendedores ambulantes de jornais em Florianópolis, a busca por justiça e os impactos do Estatuto da Criança e do Adolescente na definição de políticas públicas.

Com formato e léxico que a distancia do grande público, alheio à linguagem universitária, o destaque positivo desta coletânea, por outro lado, para não dizer da louvável diversidade temática e regional, é a conexão de pesquisadores e redes de colaboração como a Red de Estudios de la Historia de las Infancias en America Latina (REHIAL) e o GT História da Infância e da Juventude (Anpuh Nacional), células mater dos estudiosos aqui reunidos, sinalizando o crescimento e o vigor da área que ressalta habilmente a pluralidade das "infâncias" e "juventudes" na América Latina no próprio título do livro.

A comunidade acadêmica ligada à História, principal destinatária da obra - não excluindo uma gama infinita de profissionais dedicados a Educação, Direito, Psicologia e Serviços Sociais, por exemplo - ganhou, nesse sentido, um importante instrumento de reflexão. Do ponto de vista historiográfico, um novo aporte que veio endossar a tendência de se ouvir, primordialmente, as vozes das próprias crianças e jovens (como se visualiza em alguns textos) e, sob a ótica política, um suporte teórico para a defesa dos direitos infantojuvenis, mediante compreensão das vivências e desafios históricos dos sujeitos eleitos na publicação.

Batizado, logo em sua gênese, como o Século da Criança, pela escritora sueca Ellen Key, em 1907, o século XX ainda se faz presente. Seus significados, espaços, estigmas e paradigmas, voltados aos jovens e crianças, ainda ressoam na legislação, na política assistencial e educacional, no entendimento sobre o corpo e a mente infantojuvenis, assim como na indumentária e nas cores que os aprisionam - veja-se a exortação da ministra Damares Alves.

\section{REFERÊNCIAS}

FALEIROS, Vicente de Paula. Infância e processo político no Brasil. In: RIZZINI, Irene; PILOTTI, Francisco. (org.). A arte de governar crianças: a história das políticas sociais, da legislação e da assistência à infância no Brasil. 2. ed. rev. São Paulo: Cortez, 2009. p. 33-96.

LONDOÑO, Fernando Torres. A origem do conceito menor. In: PRIORE, Mary Del (org.). História da criança no Brasil. São Paulo: Contexto, 1991. p. 129-145. 
PAINS, Clarissa. "Menino veste azul e menina veste rosa", diz Damares Alves em vídeo. Disponível em: https://oglobo.globo.com/sociedade/menino-veste-azul-menina-veste-rosa-diz-damares-alves-em-video-23343024. Acesso em: 26 dez. 2019.

PASSETTI, Edson. O menor no Brasil Republicano. In: PRIORE, Mary Del (org.). História da criança no Brasil. São Paulo: Contexto, 1991. p. 146-175.

Resenha recebida em 27 de dezembro de 2019. 